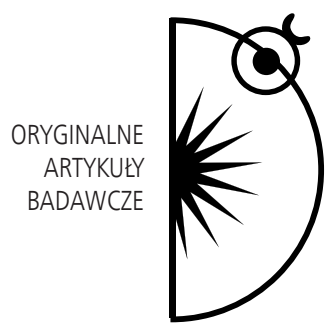

Adam Jagiełło-Rusiłowski

Hanna Solarczyk-Szwec

\title{
Kwerenda badań nad kompetencjami społecznymi w kontekście edukacji akademickiej w Polsce i na świecie*
}

DOI: http://dx.doi.org/10.12775/PBE.2013.011

\section{Teoretyczne i metodologiczne założenia kwerendy}

Celem niniejszego opracowania jest przedstawienie tej części krajowych i światowych badań nad kompetencjami społecznymi, które według obranych kryteriów mają kluczowe znaczenie zarówno dla działań podejmowanych przez interesariuszy szkolnictwa wyższego, jak i zaniechań w zakresie planowania i walidowania efektów kształcenia dotyczących kompetencji społecznych. Metodę kwerendy oparto na następujących założeniach:

\footnotetext{
* Artykuł przygotowany na podstawie materiałów zgromadzonych przez Autorów na potrzeby projektu „Opracowanie założeń merytorycznych i instytucjonalnych wdrażania Krajowych Ram Kwalifikacji oraz Krajowego Rejestru Kwalifikacji dla uczenia się przez całe życie" realizowanego przez Instytut Badań Edukacyjnych w okresie od lipca 2010 r. do końca 2013 r. w ramach Europejskiego Funduszu Społecznego Program Operacyjny „Kapitał Ludzki”, Priorytet III Wysoka jakość systemu oświaty, Poddziałanie 3.4 Otwartość systemu edukacji w kontekście uczenia się przez całe życie, Poddziałanie 3.4.1. Opracowanie i wdrożenie Krajowego Systemu Kwalifikacji.
} 
1) równoważnym traktowaniu badań na temat kompetencji społecznych istotnych do szkolnictwa wyższego w mediach drukowanych i elektronicznych,

2) ważnych badaniach - takich, które zostały opublikowane w sposób umożliwiający zrozumienie i ewentualne zweryfikowanie zastosowanej metodologii nie tylko wąskiemu gronu ekspertów, ale także przedstawicielom różnych dziedzin nauki zaangażowanych w dydaktykę akademicką,

3) dostępie do wyników i interpretacji kluczowych badań, który jest otwarty, tj. dostępny w bibliotekach, księgarniach oraz przynajmniej na poziomie ich wyszukiwania przez ogólnodostępny program Google Scholar, co daje możliwość zapoznania się z ich streszczeniem, afiliacją autorów, poziomem cytowań oraz bibliografią,

4) publikacji zawierającej najważniejsze badania, która jest możliwa do wyszukania w mediach elektronicznych po użyciu dowolnej konfiguracji następujących słów kluczy w języku angielskim (social competences/ /competency, competence-based education, key competences in education, competence requirements, competence development, professional qualifications, European/national frames, working life education, generic/transferable, employability, employee appraisal, job-related standards, career, social skills, learning outcomes, attitude, assessment, evaluation, testing, self-reports, reflection, learning process/cycle, human resources, social capital, indicators, descriptors, validation, recognition of qualifications, measurement, taxonomy, portfolio, e-portfolio, analytics, learning power, personality traits, strengths, beliefs, agency, self-efficacy, ethics, ethical stance/fibre, empathy, moral education, critical thinking, social network, brokerage, leadership, knowledge management, appreciative, sustainable, dialogical, curriculum, course, higher education, university, college, academic, science, students, graduates, problem-based/project-based, creativity, innovation pedagogy, entrepreneurship, teaching methods, learning activities, collaborative learning, student-centered, student's autonomy/responsibility, programs, campus-based practical training, volunteering, community service, in-service training, workplace learning, inquiry, research, index) oraz w języku polskim (kompetencje/kwalifikacje społeczne, kompetencje/kwalifikacje kluczowe, kompetencje/kwalifikacje miękkie, kompetencje adaptacyjne, emancypacyjne, krytyczne, zdolności społeczne, umiejętności społeczne, kapitał społeczny/intelektualny, europejskie/krajowe ramy kwalifikacji, wskaźniki, deskryptory kompetencji społecznych, walidacja kompetencji społecznych, standar- 
dy kształcenia, uczenie się społeczne, uczenie się w grupie, uczenie się wzajemne, (samo)refleksja, tożsamość, odpowiedzialność, autonomia, etyka, dialog, dyskusja, projekt, portfolio, wolontariat, profesjonalny nauczyciel, kompetentny nauczyciel akademicki, student, szkoła wyższa, uniwersytet, akademia) lub po wpisaniu nazwiska jednego ze znanych autorów.

Punktem wyjścia do przygotowania kwerendy była definicja przyjęta przez Polski Komitet Sterujący Krajowych Ram Kwalifikacji określająca kompetencje społeczne jako: „Udowodnioną (w pracy, nauce oraz w rozwoju osobistym) zdolność stosowania posiadanej wiedzy i umiejętności z uwzględnieniem zinternalizowanego systemu wartości. Kompetencje społeczne określa się bazując na kategoriach odpowiedzialności i autonomii"”.

Definicja ta jest punktem wyjścia do planowania i walidacji efektów kształcenia oraz pracy dydaktycznej, która łączy teorię z praktyką, tj. wiedzę z umiejętnościami w kontekście wartości i postaw zdefiniowanych pod postacią kompetencji społecznych. Z przytoczonych definicji wynikają nowe zadania uczelni wykraczające poza utrwalone tradycją przekazywanie wiedzy akademickiej związanej ze studiowanym kierunkiem kształcenia oraz ćwiczenie wybranych umiejętności praktycznych wymaganych przez pracodawców, obejmując swoim zasięgiem rozwijanie kompetencji społecznych bazujących w Polskiej Ramie Kwalifikacji na kategoriach tożsamości, współpracy i odpowiedzialności. W Europejskiej Ramie Kwalifikacji efekty uczenia się, zdefiniowane w kolumnie „kompetencje dla szkolnictwa wyższego”, wiążą się wyraźnie z zadaniami o charakterze zawodowym, natomiast w Polskiej Ramie Kwalifikacji przyjęto szersze rozumienie kompetencji ${ }^{2}$, czego wyrazem jest zaakcentowanie szczególnych potrzeb Polski i Polaków w zakresie kompetencji społecznych. Wynikają one zarówno z potocznej obserwacji, jak i naukowej diagnozy obszarów składających się na kapitał społeczny, tj. deficytów w zakresie: zaufania społecznego, poziomu aktywności obywatelskiej, struktury organizacji pozarządowych, potencjału kulturowego i kreatywnego oraz postaw i wyznawanych wartości ${ }^{3}$. Jeśli przyjmiemy, że szczególnym zadaniem uczelni wyższych jest formowanie tzw. klasy kreatywnej, która przyczyni się do przekształcenia kapi-

${ }^{1}$ Stownik kluczowych pojęć zwiazanych z krajowym systemem kwalifikacji, http://www.ibe.edu. $\mathrm{pl} / \mathrm{pl} /$ component/content/category/17-wydawnictwo (dostęp: 25.08.2012).

${ }^{2}$ E. Chmielecka, Kompetencje personalne i społeczne, w: Autonomia programowa uczelni. Ramy Kwalifikacji dla szkolnictwa wyższego, www.nauka.gov.pl (dostęp: 12.09.2012).

${ }^{3}$ M. Nowak-Dziemianowicz, H. Solarczyk-Szwec, Spoleczno-kulturowe uwarunkowania kompetencji spolecznych [w druku]. 
tału przetrwania w kapitał rozwoju (Raport Polska 2030 ${ }^{4}$ ), to kluczem do tego jest rozwijanie u studentów kompetencji emancypacyjnych i krytycznych służących nie tylko jednostce, ale przede wszystkim wspólnocie/społeczeństwu.

Diagnoza kompetencji przyjętych w rozporządzeniu nr 1520 MNiSW dla poszczególnych obszarów kształcenia akademickiego wykonana przez Nowak-Dziemianowicz ${ }^{5}$ wykazała istotny niedobór kompetencji emancypacyjnych i krytycznych, co stało się przyczyną ponownej dyskusji nad rozumieniem i definiowaniem kompetencji społecznych w Polskiej Ramie Kwalifikacji. W nowym ujęciu kluczowymi pojęciami rozwijanymi w ramach kompetencji społecznych na wszystkich poziomach kwalifikacji i w ich obrębie są pojęcia: tożsamości, współpracy oraz odpowiedzialności. Jednocześnie przyjęto założenie o zrównoważonym rozwoju wiedzy, umiejętności i kompetencji społecznych o charakterze adaptacyjnym, emancypacyjnym i krytycznym, gdzie kompetencje adaptacyjne to zdolności techniczne, pozwalające efektywnie i skutecznie wykonywać zadania, realizować badania, odnaleźć się na rynku pracy, reagować na zmiany przez trening umiejętności, mobilność, zespołowe rozwiązywanie problemów itp., kompetencje emancypacyjne to zdolności podmiotowe, pozwalające na rozumienie otaczającej rzeczywistości, własnego działania oraz jego konsekwencji oraz na dokonywanie wyborów w oparciu o własne potrzeby, uzasadnienia, wartości, ze świadomością konsekwencji związanych z tymi wyborami. Kompetencje krytyczne to zdolności dialogowe, pozwalające na uzasadnianie własnych poglądów i swojego działania z różnorodnych perspektyw, wykrywanie niespójności wszelkich uprawomocnień, ujawnianie ideologicznych źródeł praktyki społecznej, demaskatorską analizę dyskursu władzy, gry interesów, dominacji, empatię i racjonalne uzasadnienie własnego sprzeciwu wobec przemocy symbolicznej czy niesprawiedliwości. To także zdolność do stosowania wiedzy i umiejętności oparta na misyjności - ma służyć dostrzeganiu luk w dotychczasowym dorobku naukowym i praktyce życiowej jako przestrzeni partnerskich negocjacji rozwiązań, własnej i kolektywnej kreatywności, wnoszenia wartości dodanej na rzecz zarówno dobrobytu, jak i dobrostanu ogółu społeczeństwa.

U podstaw powyższych kompetencji leży założenie, że uczelnia i jej nauczyciele mają studentom pomóc w nadaniu zdobytej wiedzy i umiejętnościom osobistego sensu, rozumieniu własnych motywacji, dokonywaniu krytycznych wyborów w oparciu o przyjęty dobrowolnie system wartości. Zdobycie tego

\footnotetext{
${ }^{4}$ http://zds.kprm.gov.pl/node/15 (dostęp: 15.10.2012).

${ }^{5}$ M. Nowak-Dziemianowicz, H. Solarczyk-Szwec, op. cit.
} 
rodzaju kompetencji jest warunkiem osiągnięcia efektów kształcenia na danym poziomie kwalifikacji i odniesienia ich do Europejskiej Ramy Kwalifikacji.

Przygotowując niniejszą kwerendą, założyliśmy za Le Deistem i Wintertonem, że jednolite ujęcie teoretyczne kompetencji społecznych czy kluczowych jest $\mathrm{z}$ góry skazane na niepowodzenie ze względu na różnorodność perspektyw, wzajemne wykluczanie się paradygmatów naukowych i grę interesów społeczno-politycznych, wreszcie ich kulturową arbitralność ${ }^{6}$. Zamieszanie wokół pojęcia kompetencji społecznych wynika przynajmniej częściowo z obiektywistycznych poszukiwań służących jedynie słusznemu definiowaniu uczenia się opartego na kompetencjach ${ }^{7}$. Zamiast ustalania bezwzględnie obowiązującej definicji na potrzeby niniejszej kwerendy przyjęliśmy - w nurcie badań nad akademicką edukacją na rzecz zrównoważonego rozwoju trzech typów kompetencji społecznych: adaptacyjnych, emancypacyjnych i krytycznych - konstruktywistyczne podejście mające na celu rozumienie kompetencji adekwatne do kontekstu kulturowego, w której jest ona używana przez interesariuszy ${ }^{8}$. Wspólne elementy definicji kompetencji to „synergia wiedzy, umiejętności i postaw" z powodzeniem zastosowana do ,wykonywania złożonych zadań w autentycznym środowisku (np. pracy)”, według „,norm lub kryteriów wymaganych przez te środowiska" .

Kolejnym założeniem przy sporządzaniu kwerendy było to, że wymóg udowodnienia kompetencji społecznych w pracy, nauce i rozwoju osobistym implikuje połączenie oceny przynajmniej trzech interesariuszy procesu kształcenia: pracodawcy lub eksperta danej branży, nauczyciela/mentora i samego studenta jako uczącego i rozwijającego się podmiotu. Walidacja ma więc opierać się na konwergencji lub triangulacji ocen i przez to wzbudzać zaufanie zarówno lokalnych interesariuszy, jak i wszystkich lokalnych czy globalnych podmiotów uznawania kwalifikacji w ramach mobilności podczas studiowania oraz później na rynku pracy. Stąd tak ważne jest poszukiwanie badań metod walidacji spójnych z aktualnym stanem wiedzy o predykatywności ocen kompetencji co do

${ }^{6}$ F. D. Le Deist, J. Winterton, What is competence?, "Human Resource Development International" 2005, Vol. 8, No 1, s. 27-46.

${ }^{7}$ E. Stringfellow, F. D. Le Deist, J. Winterton, Typology of knowledge, skills and competences: clarification of the concept and prototype, Office for Official Publications of the European Communities, Luxembourg 2006.

${ }^{8}$ A. Stoof, R. L. Martens, J. J. G. van Merriënboer, T. J. Bastiaens, The boundary approach of competence: a constructivist aid for understanding and using the concept of competence, "Human Resource Development Review" 2002, Vol. 1, s. 345-365.

${ }^{9}$ J. de Kraker, A. Lansu, R. van Dam-Mieras (eds.), Crossing boundaries. Innovative learning for sustainable development in higher education, VAS, Frankfurt on the Main 2007. 
przyszłego funkcjonowania studentów w sferze zawodowej i społecznej, ich wkładu w rozwój organizacji i społeczności, w których przyjdzie im żyć.

Efektem przyjętych założeń jest zestawienie anglojęzycznych (zał. nr 1) i polskich (zał. nr 2) publikacji zidentyfikowanych w Google scholar oraz w zasobach bibliotecznych Uniwersytetu Mikołaja Kopernika (zał. nr 3 ) na temat kompetencji społecznych, które mogą mieć znaczenie dla szkolnictwa wyższego w kontekście wdrażania Krajowych Ram Kwalifikacji. Na tej podstawie dokonano klasyfikacji badań nad kompetencjami społecznymi w odniesieniu do pełnionych przez uczelnie wyższych funkcji: adaptacyjnej i emancypacyjno-krytycznej oraz oczekiwanych w Krajowych Ramach Kwalifikacji kompetencji.

Dla badań nad kompetencjami społecznymi w nurcie adaptacyjnym reprezentatywne są:

1. Model kompetencyjny Rodriguez ${ }^{10}$.

2. Badanie kompetencji w ramach Bilansu Kapitału Ludzkiego w Polsce w latach 2010-2011'.

3. Badania kompetencji społecznych studentów za pomocą Kwestionariusza Kompetencji Społecznych Matczak ${ }^{12}$.

4. Zapotrzebowanie pracodawców na tzw. kompetencje miękkie absolwentów kierunków ścisłych ${ }^{13}$.

5. Międzykulturowe badania oczekiwań pracodawców wobec informatyków ${ }^{14}$.

Dla badań nad kompetencjami społecznymi w nurcie emancypacyjno-krytycznym reprezentatywne są:

1. Badania Nonaki i Takeuchiego o dzieleniu się wiedzą (dostępną i ukrytą) w przedsiębiorstwie ${ }^{15}$.

${ }^{10}$ D. Rodgriguez et al., Developing competency model to promote integrated human resource practices, "Human Resource Management" 2002, Vol. 41.

${ }^{11}$ Bilans Kapitatu Ludzkiego w Polsce. Raport podsumowujacy pierwsza edycję badań realizowana w 2010 r., http://bkl.parp.gov.pl/projekt (dostęp: 25.08.2012).

${ }^{12} \mathrm{~K}$. Bobrowska-Jabłońska, Znaczenie inteligencji emocjonalnej $i$ kompetencji społecznych w kształceniu w SGH - raport z badań, 2003, http://www.e-mentor.edu.pl/artykul/index/numer/2/ id/17 (dostęp: 25.08.2012).

${ }^{13}$ A. Podgórski, Raport z badania A. Podgórski, Zapotrzebowanie pracodawców województwa kujawsko-pomorskiego na tzw. kompetencje miękkie absolwentów kierunków ścistych, Torun - Informator 2010, s. 44, https://www.biurokarier.umk.pl/publikacje-kdp (dostęp: 29.11.2012).

${ }^{14}$ A. Faheem, L. Fernando Capretz, P. Campbell, Evaluating the Demand for Soft Skills in Software Development, "IT Professional" January-February 2012, Vol. 14, No. 1, s. 44-49.

${ }^{15}$ I. Nonaka, H. Takeuchi, The Knowledge-Creating Company, Oxford University Press, New York 1995. 
2. Badania REFLEX absolwentów na europejskim rynku pracy ${ }^{16}$.

3. Badania nad rozwojem etycznym i namysłem krytycznym jako efektem kształcenia akademickiego w USA ${ }^{17}$.

4. Badanie odpowiedzialności studentów w Polsce ${ }^{18}$.

\section{Wnioski}

Ilościowa analiza kwerendy badań na temat kompetencji społecznych w kontekście edukacji akademickiej w Polsce i na świecie pozwala sformułować następujące wnioski:

1. Publikacji anglojęzycznych wyszukanych w Google Scholar według haseł wskazanych we wstępie zidentyfikowano 91. Spośród tych pozycji wskazano cztery najwyżej cytowane i reprezentatywne badania dla wskazanych nurtów eksploracji i interpretacji kompetencji społecznych.

2. Publikacji w języku polskim wyszukanych w Google scholar według haseł wskazanych we wstępie zidentyfikowano 10; spośród nich żadna nie spełniała warunków sformułowanych dla omawianej kwerendy. W związ$\mathrm{ku}$ z tym wykonano kwerendę tradycyjną, opartą na zbiorach biblioteki uniwersyteckiej UMK, co umożliwiło zidentyfikowanie 26 pozycji książkowych, i w jej następstwie odnaleźć dalsze pozycje spełniające warunki kwerendy. To pozwoliło na uwzględnienie czterech badań polskich na temat kompetencji społecznych w środowisku akademickim, tym samym wyczerpało zasadniczo zasób badań na ten temat. Okazało się bowiem, że kompetencje są w literaturze polskiej tematem nadal nowym, mocno związanym z edukacją (głównie nauczycieli i uczniów, w tym upośledzonych) i od niedawna ze sferą pracy zawodowej, co przekłada się na zainteresowanie kompetencjami zawodowymi, gdzie marginalnie i tylko w nurcie adaptacyjnym uwzględnia się kompetencje społeczne.

3. Na podstawie analizy ilościowej źródeł anglo- i polskojęzycznych można z całą pewnością stwierdzić, że dominują badania kompetencji społecznych uprawiane w nurcie adaptacyjnym (ilościowym), co nie zaskakuje

\footnotetext{
${ }^{16}$ J. Allen, R. Valden, Flexible Professional in the Knowledge Society, Springer 2010; E. Bjornali, L. Storen, Examining competence factors that encourage innovative behaviour by European higher education graduate professional, "Journal of Small Business and Enterprise Development" 2012, Vol. 19, No 3.

${ }^{17}$ W. Perry, Forms of Intellectual and Ethical Development in the College Years: A Scheme. Jossey-Bass Higher and Adult Education Series, San Francisco 1999.

${ }^{18}$ L. Marek, Ku odpowiedzialności w studiowaniu pedagogiki, Toruń 2009.
} 
w kontekście przewagi dyskursu ideologii neoliberalnej w życiu społecznym, politycznym i gospodarczym. Tym niemniej także te badania dostarczają nierzadko ciekawych danych, inspirujących hipotez, użytecznych modeli kompetencji (np. model Rodriguez). Ograniczenia badań typu ilościowego wynikają ze specyfiki paradygmatu badawczego, który zasadniczo weryfikuje przekonania badacza, a nie badanego $\mathrm{Z}$ założenia zamknięty katalog kompetencji nie otwiera badacza na nowe zjawiska, a przyjęcie adaptacyjnego zestawu kompetencji przynosi wyniki, które mogłyby świadczyć o braku znaczenia kompetencji emancypacyjnych i krytycznych, chociaż w rzeczywistości jest inaczej, co pokazują badania i interpretacja danych na przykładzie międzykulturowych badań oczekiwań pracodawców wobec informatyków.

4. Wzrasta liczba i znaczenie badań nad kompetencjami emancypacyjnymi i krytycznymi w środowisku akademickim oraz w kontekście pracy zawodowej w świecie, ale tendencja ta nie jest jeszcze widoczna w Polsce, chociaż pojawiają się już jej pierwsze oznaki - przykładem są uwzględnione $\mathrm{w}$ kwerendzie badania Marek nad jedną $\mathrm{z}$ kategorii kompetencji społecznych - odpowiedzialnością. Badania w tym nurcie oparte są często na metodologii badań jakościowych, co przynosi innego typu ograniczenia - czasochłonność, wysokie koszty, subiektywizm. Wartościowym kompromisem są badania nad krytycznym namysłem King i Kitchener, które na bazie danych jakościowych opracowały diagnostyczne narzędzia badawcze zbudowane na metodologii badań ilościowych, pozwalające ocenić skuteczność programów kształcenia w zakresie badanej (krytycznej) kompetencji.

Jakościowa analiza zgromadzonych w ramach kwerendy danych pozwala w tym miejscu na wskazanie najważniejszych i najciekawszych naszym zdaniem wniosków i propozycji wynikających z poszczególnych badań:

1. Model Rodriguez przynosi wzorce definiujące zachowania charakterystyczne dla pięciu poziomów kompetencji. Banchmark na optymalnym (piątym poziomie) wymaga od pracownika wzbudzenia w całym zespole przynależności i dumy oraz wymiernego wkładu w skuteczne strategie działań zespołu. W opinii Rodriguez, a wyniki cytowalności zdają się to potwierdzać, ocena kompetencji za pomocą wystandaryzowanej skali może być dla pracodawców solidną podstawą decyzji o zatrudnieniu, awansie czy planach szkoleniowych.

2. Badania kompetencji prowadzone w ramach Bilansu Kapitału Ludzkiego, oparte na samoocenie studentów i absolwentów szkół wyższych oraz 
ocenie ze strony pracodawców, wskazują na to, że podstawową determinantą kompetencji jest wykształcenie, następnie kierunek studiów i płeć. Badani są też świadomi konieczności dalszego dokształcania (chociaż te same badania mówią o $80 \%$ dorosłych biernych edukacyjnie). Na podstawie badań sformułowano tezę o nadmiarze kwalifikacji (zjawisko przeedukowania) oraz niedoborze kompetencji, szczególnie - społecznych (rozumianych w badaniach adaptacyjnie). Tezę o luce kompetencyjnej weryfikują badania REFLEX absolwentów na europejskim rynku pracy, według których $25 \%$ pracowników nie ma w pracy okazji do wykorzystania swoich kompetencji, szczególnie o charakterze krytycznym i innowacyjnym. Można zatem z dużym prawdopodobieństwem założyć, że dotyczy to w Polsce dużo wyższego odsetka pracowników, co nie skłania m.in. do dalszego kształcenia.

3. Badania dotyczące zapotrzebowania pracodawców województwa kujawsko-pomorskiego na tzw. kompetencje miękkie absolwentów kierunków ścisłych wskazują na zadowolenie pracodawców z kompetencji pracowników z wyższym wykształceniem. Pozwala to na sformułowanie hipotezy, która wymaga dalszych badań, że luka kompetencyjna w większym stopniu dotyczy osób z niższym wykształceniem. Inne badania pracodawców na temat oczekiwań wobec uczelni wyższych wskazują na większe rozbieżności między oczekiwaniami przedsiębiorców a wyrabianiem pożądanych cech przez szkoły wyższe.

4. Badania kompetencji społecznych studentów SGH za pomocą psychologicznego narzędzia - Kwestionariusza Kompetencji Społecznych - pokazują, że wysokie i średnie wyniki w zakresie kompetencji społecznych uzyskało 85,7\% studentów SGH. Osoby, które uzyskują wyższe wyniki w Kwestionariuszu Kompetencji Społecznych, są zadowolone ze studiów oraz z wykonywanej pracy. Nie wykazano związku pomiędzy średnią ze studiów i kompetencjami społecznymi. Generalnie studenci lepiej radzą sobie w sytuacjach wymagających kompetencji warunkujących zachowania asertywne i w sytuacjach ekspozycji społecznej niż w bliskich relacjach interpersonalnych. W odpowiedzi na pytanie co determinuje poziom kompetencji społecznych sformułowano hipotezę spirali. Osoby charakteryzujące się wysokimi kompetencjami wybierają aktywności, zajęcia, gdzie doskonalą swoje kompetencje, natomiast osoby, które czują się niepewne w tym zakresie wybierają zajęcia, które nie sprzyjają w takim stopniu rozwojowi kompetencji. 
5. Międzykulturowe badania oczekiwań pracodawców wobec informatyków pokazują zróżnicowanie zapotrzebowania na indywidualną innowacyjność i kreatywność pod względem kulturowym. Jest ono aż dwukrotnie silniejsze w Ameryce Północnej niż w Europie i trzykrotnie silniejsze niż w Azji, co wyjaśnia m.in. przewagę Amerykanów w liczbie innowacji na świecie. Warto też zwrócić uwagę, że taki wniosek można było sformułować dopiero, kiedy wzięto pod uwagę wymagania na poszczególne stanowiska pracy zajmowane przez informatyków oraz po uwzględnieniu kulturowego kontekstu. Uśrednione wyniki jednoznacznie wskazywały na kompetencje komunikacyjne jako najbardziej pożądane na całym świecie.

6. Przytaczane w tekście badania Nonaki i Takeuchiego o dzieleniu się wiedzą $\mathrm{w}$ przedsiębiorstwie podkreślają znaczenie kompetencji społecznych w przekształcaniu wiedzy ukrytej w wiedzę dostępną dla każdego w organizacji. Tego rodzaju kompetencje zdobywa się przez dzielenie się wiedzą w zespole ludzi rozwiązujących zadanie, którzy rozumieją wartość konstruowania nowej wiedzy z innymi w ramach ,gęstych” sieci, budowania zaufania potrzebnego do podważania dotychczasowych teorii i metodologii badań, otwartej wymiany pomysłów i przekraczania (transcendecji) zastanej rzeczywistości w oparciu o solidną wiedzę.

7. W badaniach norweskich absolwentów, inspirowanych raportem REFLEX, na europejskim rynku pracy pokazano, że uczelnie przyczyniają się do dostarczania gospodarce innowatorów i wspierających ich współpracowników wtedy, gdy walidują u swoich studentów wiedzę, umiejętności i postawy dotyczące kreatywnego rozwiązywania problemów, dialogowania za pomocą różnorodnych mediów i dyskursów, przywództwa typu niehierarchicznego (płaskiego) oraz kompetencje brokerskie. Ich nabywaniu służą te elementy programu kształcenia, które są realizowane przez uczenie problemowe (PBL), warsztaty przedsiębiorczości i kreatywności, co potwierdzają także wyniki innych badań.

8. W badaniach nad rozwojem etycznym najwyżej cytowaną pozycją jest książka Perry’ego, który zaproponował złożony z dziewięciu stadiów model rozwoju etycznego. Z kolei ważnym rezultatem badań King i Kitchener nad krytycznym namysłem było wypracowanie narzędzi badawczych, które pozwalają ocenić skuteczność programów kształcenia oraz potwierdzają przydatność takich form kształcenia jak: symulacje, rozwiązywanie problemów rozbieżnych, projekty międzynarodowe z elementami kursów na odległość. 
9. Polskie badania nad odpowiedzialnością studentów przynoszą wyniki, które mówią, że aż $25 \%$ studentów charakteryzuje niski poziom odpowiedzialności, a tylko 14\% wykazuje wysoki poziom odpowiedzialności. Badani studenci deklarują wysoki poziom poczucia odpowiedzialności zarówno podmiotowej (za siebie), jak i społecznej (za innych) oraz niski poziom odpowiedzialności historycznej (za przyszłość następnych pokoleń, za przeszłość historyczną, za środowisko naturalne). Autorka badań postuluje kierowanie się założeniami pedagogiki emancypacyjnej w budowaniu kultury uczenia się sprzyjającej rozwojowi odpowiedzialności.

\section{Bibliografia}

Ahmed F., Fernando Capretz L., Campbell P., Evaluating the Demand for Soft Skills in Software Development, "IT Professional” January-February 2012, Vol. 14, No. 1, s. 44 -49, DOI: http://dx.doi.org/10.1109/MITP.2012.7.

Allen J., Valden R., Flexible Professional in the Knowledge Society, Springer 2010.

Bjornali E., Storen L., Examining competence factors that encourage innovative behaviour by European higher education graduate Professional, "Journal of Small Business and Enterprise Development" 2012, Vol. 19, No 3, DOI: http://dx.doi. org/10.1108/14626001211250135.

de Kraker J., Lansu A., van Dam-Mieras R. (eds.), Crossing boundaries. Innovative learning for sustainable development in higher education, VAS, Frankfurt on the Main 2007.

Le Deist F. D., Winterton J., What is competence?, "Human Resource Development International" 2005, Vol. 8, No 1, s. 27-46.

Marek L., Ku odpowiedzialności w studiowaniu pedagogiki, Wydawnictwo Adam Marszałek,Toruń 2009.

Nonaka I., Takeuchi H., The Knowledge-Creating Company, Oxford University Press, New York 1995.

Nowak-Dziemianowicz M., Solarczyk-Szwec H., Społeczno-kulturowe uwarunkowania kompetencji społecznych [w druku].

Perry W., Forms of Intellectual and Ethical Development in the College Years: A Scheme, Jossey-Bass Higher and Adult Education Series, San Francisco 1999.

Rodgriguez D. et al., Developing competency model to promote integrated human resource practices, "Human Resource Management" 2002, Vol. 41.

Stoof A., Martens R. L., van Merriënboer J. J. G., Bastiaens T. J., The boundary approach of competence: a constructivist aid for understanding and using the concept of competence, "Human Resource Development Review" 2002, Vol. 1, s. 345-365. 
Stringfellow E., Le Deist F. D., Winterton J., Typology of knowledge, skills and competences: clarification of the concept and prototype, Office for Official Publications of the European Communities, Luxembourg 2006.

\section{Netografia}

Bilans Kapitału Ludzkiego w Polsce. Raport podsumowujący pierwsza edycję badań realizowana w 2010 r., http://bkl.parp.gov.pl/projekt (dostęp: 25.08.2012).

Bobrowska-Jabłońska K., Znaczenie inteligencji emocjonalnej i kompetencji społecznych w kształceniu $w$ SGH - raport z badań, w: e-mentor, 2003, 2, http://www.e-mentor. edu.pl/artykul/index/numer/2/id/17 (dostęp: 25.08.2012).

Chmielecka E., Kompetencje personalne i spoteczne, w: Autonomia programowa uczelni. Ramy Kwalifikacji dla szkolnictwa wyższego; www.nauka.gov.pl (dostęp: 12.09.2012).

Podgórski A. (2010), Raport z badania: A. Podgórski, Zapotrzebowanie pracodawców województwa kujawsko-pomorskiego na tzw. kompetencje miękkie absolwentów kierunków ścistych, „Toruń - Informator”, s. 44; https://www.biurokarier.umk.pl/publikacje-kdp (dostęp: 29.11.2012).

Słownik kluczowych pojęć zwiąanych z krajowym systemem kwalifikacji, http://www.ibe. edu.pl/pl/component/content/category/17-wydawnictwo (dostęp: 25.08.2012).

\section{Aneks}

Załączniki:

Nr 1: Anglojęzyczne publikacje w Google Scholar.

$\mathrm{Nr}$ 2: Polskojęzyczne publikacje w Google Scholar.

$\mathrm{Nr}$ 3: Kwerenda biblioteczna w Uniwersytecie Mikołaja Kopernika. 
Załącznik nr 1: Anglojęzyczne publikacje w Google Scholar

\begin{tabular}{|c|c|c|c|}
\hline Lp. & Nazwa badania/Autor i tytuł publikacji & $\begin{array}{l}\text { Liczba } \\
\text { cytowań } \\
\text { w Google } \\
\text { Scholar }\end{array}$ & $\begin{array}{c}\text { Współczynnik } \\
\text { ważności }\end{array}$ \\
\hline 1 & $\begin{array}{l}\text { Rodgriguez D. et al., Developing competency model } \\
\text { to promote integrated human resource practices, "Human } \\
\text { Resource Management" } 2002 \text {, Vol. 41, s. 309-324. }\end{array}$ & 24000 & 2400,00 \\
\hline 2 & $\begin{array}{l}\text { Nonaka I., Takeuchi H., The Knowledge-Creating Company, } \\
\text { Oxford University Press, New York } 1995 .\end{array}$ & 27966 & 1645,06 \\
\hline 3 & $\begin{array}{l}\text { Harris R. et al., Competency based education and training: } \\
\text { between a rock and a whirlpool, Macmillan Educational, } \\
\text { South Melbourne, Australia 1995. }\end{array}$ & 18000 & 1058,82 \\
\hline 4 & $\begin{array}{l}\text { Allen J., Valden R., Flexible Professional in the Knowledge } \\
\text { Society, Springer } 2010 . \\
\text { Bjornali E., Storen L., Examining competence factors that } \\
\text { encourage innovative behaviour by European higher } \\
\text { education graduate Professional, "Journal of Small Business } \\
\text { and Enterprise Development" 2012, Vol. 19, No. 3, } \\
\text { DOI: http://dx.doi.org/10.1108/14626001211250135. }\end{array}$ & 1318 & 659,00 \\
\hline 5 & $\begin{array}{l}\text { Smith B., Building managers from the inside out: } \\
\text { competency based action learning, "Journal of } \\
\text { Management Development" 1993, Vol. 12, No. 1, } \\
\text { s. 43-48, } \\
\text { DOI: http://dx.doi.org/10.1108/02621719310024381. }\end{array}$ & 10500 & 552,63 \\
\hline 6 & $\begin{array}{l}\text { Jones L., Moore R., Appropriating competence: the } \\
\text { competency movement, the New Right and the "culture } \\
\text { change" project, "British Journal of Education and Work" } \\
\text { 1995, Vol. 8, No. 2, s. 78-92, } \\
\text { DOI: http://dx.doi.org/10.1080/0269000950080206. }\end{array}$ & 8480 & 498,82 \\
\hline 7 & $\begin{array}{l}\text { Stoof A. et al., The boundary approach of competence: } \\
\text { a constructivist aid for understanding and using the } \\
\text { concept of competence, "Human Resource Development } \\
\text { Review" 2002, Vol. 1, No. 3, s. 345-365, DOI: http:// } \\
\text { dx.doi.org/10.1177/1534484302013005. }\end{array}$ & 4780 & 478,00 \\
\hline 8 & $\begin{array}{l}\text { Green P. C., Building robust competencies, CA: Jossey-Bass, } \\
\text { San Francisco } 1999 .\end{array}$ & 5630 & 433,08 \\
\hline 9 & $\begin{array}{l}\text { Woodruffe C., Assessment centres: identifying and } \\
\text { developing competence, Institute of Personnel } \\
\text { Management, London } 1990 .\end{array}$ & 9520 & 432,73 \\
\hline 10 & $\begin{array}{l}\text { Perry W., Forms of Intellectual and Ethical Development in } \\
\text { the College Years: A Scheme, Jossey-Bass Higher and Adult } \\
\text { Education Series, San Francisco } 1999 .\end{array}$ & 4888 & 376 \\
\hline 11 & $\begin{array}{l}\text { Earley P. C., Ang S., Cultural intelligence: individual } \\
\text { interactions across cultures, Stanford University Press, } \\
\text { Stanford } 2003 .\end{array}$ & 2800 & 311,11 \\
\hline
\end{tabular}


Załącznik nr 1 - cd.

\begin{tabular}{|c|c|c|c|}
\hline Lp. & Nazwa badania/Autor i tytuł publikacji & $\begin{array}{l}\text { Liczba } \\
\text { cytowań } \\
\text { w Google } \\
\text { Scholar }\end{array}$ & $\begin{array}{c}\text { Współczynnik } \\
\text { ważności }\end{array}$ \\
\hline 12 & $\begin{array}{l}\text { Keep E., Mayhew K., The assessment of knowledge, skills } \\
\text { and competitiveness, "Oxford Journal of Economic Policy" } \\
\text { 1999, Vol. 15, No. 1, s. 1-15. }\end{array}$ & 3620 & 278,46 \\
\hline 13 & $\begin{array}{l}\text { Eraut M., Developing professional knowledge and } \\
\text { competence, Falmer Press, London } 1994 .\end{array}$ & 3920 & 217,78 \\
\hline 14 & $\begin{array}{l}\text { Hay J., Managerial competences or managerial } \\
\text { characteristics?, "Management Education and } \\
\text { Development" 1990, Vol. 21, No. 4, s. 305-15, } \\
\text { DOl: http://dx.doi.org/10.1177/135050769002100404. }\end{array}$ & 4490 & 204,09 \\
\hline 15 & $\begin{array}{l}\text { Boak G., Developing managerial competences: the } \\
\text { management learning contract approach, Pitman, } \\
\text { London 1991. }\end{array}$ & 3950 & 188,10 \\
\hline 16 & $\begin{array}{l}\text { King P. M., Kitchener K. S., Developing Reflective } \\
\text { Judgment: Understanding and Promoting Intellectual } \\
\text { Growth and Critical Thinking in Adolescents and Adults, } \\
\text { Jossey-Bass Higher and Adult Education Series, } \\
\text { San Francisco } 2002 .\end{array}$ & 1742 & 174,2 \\
\hline 17 & $\begin{array}{l}\text { Novak J., Gowin D., Learning how to learn, Cambridge } \\
\text { University Press, Cambridge } 1984 .\end{array}$ & 4100 & 146,43 \\
\hline 18 & $\begin{array}{l}\text { Gerber R., Experience, common sense and expertise in } \\
\text { workplace learning, w: Gerber R., Lankshear C. (eds.), } \\
\text { Training for a smart workforce, Routledge, London } 2000 .\end{array}$ & 1500 & 125,00 \\
\hline 19 & $\begin{array}{l}\text { Elbers E., The development of competence and its social } \\
\text { context, "Educational Psychology Review" 1991, Vol. 3, } \\
\text { s. 73-94, } \\
\text { DOI: http://dx.doi.org/10.1007/BF01417919. }\end{array}$ & 2450 & 116,67 \\
\hline 20 & $\begin{array}{l}\text { Billett S., Performance at work: identifying smart work } \\
\text { practice, w: Gerber R., Lankshear C. (eds.), Training for } \\
\text { a smart workforce, Routledge, London 2000, s. 123-150. }\end{array}$ & 1230 & 102,50 \\
\hline 21 & $\begin{array}{l}\text { Boyatzis R. E., The competent manager: a model for } \\
\text { effective performance, Wiley, New York } 1982 .\end{array}$ & 2670 & 89,00 \\
\hline 22 & $\begin{array}{l}\text { Hendry C., Arthur M. B., Jones A. M., Strategy through } \\
\text { people: adaptation and learning in the small-medium } \\
\text { enterprise, Routledge, London } 1995 .\end{array}$ & 1500 & 88,24 \\
\hline 23 & $\begin{array}{l}\text { Sandberg J., Human competence at work: an interpretive } \\
\text { approach, Bas, Göteburg } 1994 .\end{array}$ & 1450 & 80,56 \\
\hline 24 & $\begin{array}{l}\text { Rees B. A., The construction of management: competence } \\
\text { and gender issues at work, Edward Elgar, London } 2003 .\end{array}$ & 581 & 64,56 \\
\hline
\end{tabular}


Załącznik nr 1 - cd.

\begin{tabular}{|c|c|c|c|}
\hline Lp. & Nazwa badania/Autor i tytuł publikacji & $\begin{array}{l}\text { Liczba } \\
\text { cytowań } \\
\text { w Google } \\
\text { Scholar }\end{array}$ & $\begin{array}{c}\text { Współczynnik } \\
\text { ważności }\end{array}$ \\
\hline 25 & $\begin{array}{l}\text { Boreham N., Work process knowledge, curriculum control } \\
\text { and the work-based route to vocational qualifications, } \\
\text { "The British Journal of Educational Studies" 2002, Vol. 50, } \\
\text { No. 2, s. } 225-237 \text {, } \\
\text { DOI: http://dx.doi.org/10.1111/1467-8527.00199. }\end{array}$ & 591 & 59,10 \\
\hline 26 & $\begin{array}{l}\text { Brown R. B., Reframing the competency debate: } \\
\text { management knowledge and meta-competence in } \\
\text { graduate education, "Management Learning" 1994, } \\
\text { Vol. 25, No. 2, s. 289-99. }\end{array}$ & 1050 & 58,33 \\
\hline 27 & $\begin{array}{l}\text { Stasz C., Do employers need the skills they want? Evidence } \\
\text { from technical work, "Journal of Education and Work" } \\
\text { 1997, Vol. 10, No. 3, s. 205-233, } \\
\text { DOI: http://dx.doi.org/10.1080/1363908970100301. }\end{array}$ & 680 & 45,33 \\
\hline 28 & $\begin{array}{l}\text { Cooper K. C., Effective competency modeling and } \\
\text { reporting: a step-by-step guide for improving individual } \\
\text { and organizational performance, Amacom, New York } 2000 .\end{array}$ & 486 & 40,50 \\
\hline 29 & $\begin{array}{l}\text { Wagner R. K., Sternberg R. J., Tacit knowledge and } \\
\text { intelligence in the everyday world, w: Sternberg R. J., } \\
\text { Wagner R. K. (eds.), Practical intelligence: nature and } \\
\text { origins of competence in the everyday world, Cambridge } \\
\text { University Press, Cambridge 1986, s. 51-83 }\end{array}$ & 1010 & 38,85 \\
\hline 30 & $\begin{array}{l}\text { Lei D., Hitt M. A., Bettis R., Dynamic core competences } \\
\text { through meta-learning and strategic context, "Journal of } \\
\text { Management" 1996, Vol. 22, s. 549-569, } \\
\text { DOI: http://dx.doi.org/10.1016/S0149-2063(96)90024-0. }\end{array}$ & 579 & 36,19 \\
\hline 31 & $\begin{array}{l}\text { Brockett R., Hiemstra R., Self-direction in Adult Learning; } \\
\text { Perspectives on Theory, Research and Practice, } \\
\text { New York } 1991 .\end{array}$ & 716 & 34,10 \\
\hline 32 & $\begin{array}{l}\text { Sophian S., Beyond competence: the significance of } \\
\text { performance for conceptual development, "Cognitive } \\
\text { Development" 1997, Vol. 12, s. 281-303, } \\
\text { DOI: http://dx.doi.org/10.1016/S0885-2014(97)90001-0. }\end{array}$ & 456 & 30,40 \\
\hline 33 & $\begin{array}{l}\text { Alexander B., Going Nomadic: Mobile Learning in Higher } \\
\text { Education, „Educause Review” 2004, Vol. 39, No 5, } \\
\text { s. 28-35 }\end{array}$ & 232 & 29,00 \\
\hline 34 & $\begin{array}{l}\text { Sternberg R. J., Kolligian J., Competence considered, Yale } \\
\text { University Press, New Haven } 1990 .\end{array}$ & 629 & 28,59 \\
\hline
\end{tabular}


Załącznik nr 1 - cd.

\begin{tabular}{|c|c|c|c|}
\hline Lp. & Nazwa badania/Autor i tytuł publikacji & $\begin{array}{l}\text { Liczba } \\
\text { cytowań } \\
\text { w Google } \\
\text { Scholar }\end{array}$ & $\begin{array}{c}\text { Współczynnik } \\
\text { ważności }\end{array}$ \\
\hline 35 & $\begin{array}{l}\text { Johnston R., Sampson M., The acceptable face of } \\
\text { competence, "Management Education and Development" } \\
\text { 1993, Vol. 24, No. 3, s. 216-24, } \\
\text { DOI: http://dx.doi.org/10.1177/135050769302400309. }\end{array}$ & 527 & 27,74 \\
\hline 36 & $\begin{array}{l}\text { Burgoyne J., The competence movement: issues, } \\
\text { stakeholders and prospects, "Personnel Review" 1993, } \\
\text { Vol. 22, No. 6, s. 6-13, } \\
\text { DOI: http://dx.doi.org/10.1108/EUM0000000000812. }\end{array}$ & 497 & 26,16 \\
\hline 37 & $\begin{array}{l}\text { Lucia A. D., Lepsinger R., The art and science of } \\
\text { competency models: pinpointing critical success factors } \\
\text { in organisations, Jossey-Bass, San Francisco } 1999 .\end{array}$ & 305 & 23,46 \\
\hline 38 & $\begin{array}{l}\text { Lepsinger R., Use competency models to support } \\
\text { organisational change, "Human Resource Professional" } \\
\text { 1995, Vol. 8, No. 4, s. 7-10. }\end{array}$ & 391 & 23,00 \\
\hline 39 & $\begin{array}{l}\text { Straka G. A., Measurement and evaluation of competence, } \\
\text { w: Descy P., Tessaring M. (eds.), The foundations of } \\
\text { evaluation and impact research: third report on vocational } \\
\text { training research in Europe: background report, Office } \\
\text { for Official Publications of the European Communities, } \\
\text { Luxembourg 2005, s. 263-311. }\end{array}$ & 147 & 21,00 \\
\hline 40 & $\begin{array}{l}\text { Nyhan B., Developing people's ability to learn: a European } \\
\text { perspective on self-learning competency and technological } \\
\text { change, Eurotecnet Technical Assistance Office on behalf } \\
\text { of the CEC, Brussels } 1991 .\end{array}$ & 428 & 20,38 \\
\hline 41 & $\begin{array}{l}\text { Facione P. A., Sánchez C. A., Facione N. C., Gainen J., } \\
\text { California Critical Thinking Inventory, "The Journal } \\
\text { of General Education" 1995, Vol. 44, No. 1, s. 1-25. }\end{array}$ & 301 & 17,71 \\
\hline 42 & $\begin{array}{l}\text { Guion R. M., Personnel assessment, selection and } \\
\text { placement, Consulting Psychological Press, Palo Alto, CA } \\
1991 .\end{array}$ & 371 & 17,67 \\
\hline 43 & $\begin{array}{l}\text { Barth M., Godemann J., Rieckmann J, Stoltenberg U., } \\
\text { Developing key competencies for sustainable development } \\
\text { in higher education, "International Journal of Sustainability } \\
\text { in Higher Education" 2007, Vol. 8, No 4, s. 416-430, } \\
\text { DOI: http://dx.doi.org/10.1108/14676370710823582. }\end{array}$ & 88 & 17,60 \\
\hline 44 & $\begin{array}{l}\text { Dall'Alba G., Sandberg J., Educating for competence in } \\
\text { professional practice, "Instructional Science" 1996, Vol. 24, } \\
\text { s. 411-437. }\end{array}$ & 257 & 16,06 \\
\hline 45 & $\begin{array}{l}\text { Boam R., Sparrow P. (eds.), Designing and achieving } \\
\text { competency, McGraw-Hill, London } 1992 .\end{array}$ & 302 & 15,10 \\
\hline
\end{tabular}


Załącznik nr 1 - cd.

\begin{tabular}{|c|c|c|c|}
\hline Lp. & Nazwa badania/Autor i tytuł publikacji & $\begin{array}{l}\text { Liczba } \\
\text { cytowań } \\
\text { w Google } \\
\text { Scholar }\end{array}$ & $\begin{array}{c}\text { Współczynnik } \\
\text { ważności }\end{array}$ \\
\hline 46 & $\begin{array}{l}\text { Nuthall G., Learning how to learn: the evolution of } \\
\text { students' minds through the social processes and culture } \\
\text { of the classroom, "International Journal of Educational } \\
\text { Research" 1999, Vol. 31, No. 3, s. 139-256. }\end{array}$ & 193 & 14,85 \\
\hline 47 & $\begin{array}{l}\text { Boudreaux G., Director competencies for the } 21^{\text {st }} \text { Century: } \\
\text { a guide for the new members of the board, "Management } \\
\text { Quarterly" } 1997, \text { Vol. } 37, \text { No. 4, s. 32-40. }\end{array}$ & 215 & 14,33 \\
\hline 48 & $\begin{array}{l}\text { Mangham I., In search of competence, "Journal of General } \\
\text { Management" 1986, Vol. 12, No. 2, s. 5-12. }\end{array}$ & 368 & 14,15 \\
\hline 49 & $\begin{array}{l}\text { Cheetham G., Chivers G., The reflective (and competent) } \\
\text { practitioner: a model of professional competence } \\
\text { which seeks to harmonise the reflective practitioner and } \\
\text { competence-based approaches, "Journal of European } \\
\text { Industrial Training" 1998, Vol. 22, No. 7, s. 267-276, } \\
\text { DOI: http://dx.doi.org/10.1108/03090599810230678. }\end{array}$ & 198 & 14,14 \\
\hline 50 & $\begin{array}{l}\text { O'Neil H. F. (ed.), Workforce readiness: competence and } \\
\text { assessment, Lawrence Erlbaum, New York } 1997 .\end{array}$ & 188 & 12,53 \\
\hline 51 & $\begin{array}{l}\text { Evers F. T., Berdrow I., Rush J. C., The bases of competence: } \\
\text { skills for lifelong learning and employability, Jossey Bass } \\
\text { Wiley, New York } 1998 .\end{array}$ & 159 & 11,36 \\
\hline 52 & $\begin{array}{l}\text { Dooley K. E. et al., Behaviourally anchored competencies: } \\
\text { evaluation tool for training via distance, "Human Resource } \\
\text { Development International" 2004, Vol. 7, No. 3, } \\
\text { s. 315-332, } \\
\text { DOI: http://dx.doi.org/10.1080/1367886042000210958. }\end{array}$ & 79 & 9,88 \\
\hline 53 & $\begin{array}{l}\text { de Haan G., The BLK "21" programme in Germany: } \\
\text { A "Gestaltungskompetenz" - based model for Education } \\
\text { for Sustainable Development, "Environmental Education } \\
\text { Research" 2006, Vol. 12, s. 19-32, } \\
\text { DOI: http://dx.doi.org/10.1080/13504620500526362. }\end{array}$ & 59 & 9,83 \\
\hline 54 & $\begin{array}{l}\text { Thompson J. E., Stuart R., Lindsay P. R., The competence } \\
\text { of top teams members: a framework for successful } \\
\text { performance, "Journal of Managerial Psychology" 1996, } \\
\text { Vol. 11, No. 3, s. 48-66, } \\
\text { DOI: http://dx.doi.org/10.1108/02683949610113593. }\end{array}$ & 148 & 9,25 \\
\hline 55 & $\begin{array}{l}\text { Bjørnåvold J., Making learning visible: identification, } \\
\text { assessment and recognition of non-formal learning in } \\
\text { Europe, (Cedefop Reference series), Office for Official } \\
\text { Publications of the European Communities, } \\
\text { Luxembourg } 2000 .\end{array}$ & 108 & 9,00 \\
\hline
\end{tabular}


Załącznik nr 1 - cd.

\begin{tabular}{|c|c|c|c|}
\hline Lp. & Nazwa badania/Autor i tytuł publikacji & $\begin{array}{l}\text { Liczba } \\
\text { cytowań } \\
\text { w Google } \\
\text { Scholar }\end{array}$ & $\begin{array}{c}\text { Współczynnik } \\
\text { ważności }\end{array}$ \\
\hline 56 & $\begin{array}{l}\text { Gonzalez R., Mesanza R., Mariel P., Determinants of } \\
\text { student mobility flows: empirical study on the Erasmus } \\
\text { Program, Higher Education, Springer Journals, } \\
\text { Springer } 2011 .\end{array}$ & 9 & 9,00 \\
\hline 57 & $\begin{array}{l}\text { McClelland D., Identifying competencies with behavioural- } \\
\text { event interviews, "Psychological Science" 1998, Vol. 9, No. } \\
\text { 5, s. 331-339, } \\
\text { DOI: http://dx.doi.org/10.1111/1467-9280.00065. }\end{array}$ & 122 & 8,71 \\
\hline 58 & $\begin{array}{l}\text { Markowitsch J., Plaimauer C., Descriptors for competence: } \\
\text { towards an international standard classification for skills } \\
\text { and competences, "Journal of European Industrial Training" } \\
\text { 2009, Vol. 32, No 2/3, s. 171-186, } \\
\text { DOI: http://dx.doi.org/10.1108/03090590910993652. }\end{array}$ & 26 & 8,67 \\
\hline 59 & $\begin{array}{l}\text { Bell J., Dale M., Informal learning in the workplace. } \\
\text { Sheffield: Department for Education and Employment, } \\
\text { "Research Report" 1999, Vol. } 134 .\end{array}$ & 112 & 8,62 \\
\hline 60 & $\begin{array}{l}\text { Rothwell W. J., Lindholm J. E., Competency identification, } \\
\text { modeling and assessment in the USA, "International } \\
\text { Journal of Training and Development" 1999, Vol. 3, No. 2, } \\
\text { s. 90-105, DOI: } \\
\text { http://dx.doi.org/10.1111/1468-2419.00069. }\end{array}$ & 108 & 8,31 \\
\hline 61 & $\begin{array}{l}\text { Engle A. D. et al., Conceptualizing the global competency } \\
\text { cube: a transnational model of human resource, "Journal } \\
\text { of European Industrial Training" 2001, Vol. 25, No. 7, } \\
\text { s. } 346-353 .\end{array}$ & 91 & 8,27 \\
\hline 62 & $\begin{array}{l}\text { van der Klink M., Boon J., The investigation of } \\
\text { competencies within professional domains, "Human } \\
\text { Resource Development International" 2002, Vol. 5, No. 4, } \\
\text { s. 411-424. }\end{array}$ & 81 & 8,10 \\
\hline 63 & $\begin{array}{l}\text { Hager P., Is there a cogent philosophical argument against } \\
\text { competency standards?, "Australian Journal of Education" } \\
\text { 1994, Vol. 38, s. 3-18, } \\
\text { DOI: http://dx.doi.org/10.1177/000494419403800101. }\end{array}$ & 128 & 7,11 \\
\hline 64 & $\begin{array}{l}\text { Boon J., van der Klink M., Competencies: the triumph } \\
\text { of a fuzzy concept, "Academy of Human Resource } \\
\text { Development Annual Conference: Proceedings" 2002, } \\
\text { Vol. 1, s. 327-334. }\end{array}$ & 66 & 6,60 \\
\hline
\end{tabular}


Załącznik nr 1 - cd.

\begin{tabular}{|c|c|c|c|}
\hline Lp. & Nazwa badania/Autor i tytuł publikacji & $\begin{array}{l}\text { Liczba } \\
\text { cytowań } \\
\text { w Google } \\
\text { Scholar }\end{array}$ & $\begin{array}{c}\text { Współczynnik } \\
\text { ważności }\end{array}$ \\
\hline 65 & $\begin{array}{l}\text { Harvey M. G., Speier C., Novicevic M. M., An innovative } \\
\text { global management staffing system: a competency-based } \\
\text { perspective, "Human Resource Management" 2000, Vol. } \\
\text { 39, No. 4, s. 381-394, } \\
\text { DOI: http://dx.doi.org/10.1002/1099- } \\
\text { 050X(200024)39:4<381::AID-HRM8>3.0.CO;2-K. }\end{array}$ & 79 & 6,58 \\
\hline 66 & $\begin{array}{l}\text { Zawacki-Richter O., Hanft A., Bäcker E. M., Validation } \\
\text { of Competencies in E-Portfolios: A Qualitative Analysis, } \\
\text { "The International Review of Research in Open } \\
\text { and Distance Learning" 2011, Vol. 12, No } 1 .\end{array}$ & 6 & 6,00 \\
\hline 67 & $\begin{array}{l}\text { Dubois D. A., Rothwell W. J., Competency-based human } \\
\text { resource management, Davies-Black, Palo-Alto, CA } 2004 .\end{array}$ & 40 & 5,00 \\
\hline 68 & $\begin{array}{l}\text { Elkin G., Competency-based human resource development, } \\
\text { "Industrial and Commercial Training" 1990, Vol. 22, } \\
\text { No. 4, s. 20-25, } \\
\text { DOI: http://dx.doi.org/10.1108/00197859010137009. }\end{array}$ & 108 & 4,91 \\
\hline 69 & $\begin{array}{l}\text { Dulewicz V., Assessment centres as the route to } \\
\text { competence, "Personnel Management" 1989, November, } \\
\text { s. 56-59. }\end{array}$ & 109 & 4,74 \\
\hline 70 & $\begin{array}{l}\text { Street D., Brown S., Shramm C., Gillespie K., The impact of } \\
\text { In-Class Tutoring Program on Student Social Capital, ASEE/ } \\
\text { /IEEE Frontiers in Education, IEEE Press Piscataway, NJ, USA } \\
\text { 2009, DOI: http://dx.doi.org/10.1109/FIE.2009.5350569. }\end{array}$ & 14 & 4,67 \\
\hline 71 & $\begin{array}{l}\text { Naquin S. S., Wilson J., Creating competency standards, } \\
\text { assessments and certification. "Advances in Developing } \\
\text { Human Resources" 2002, Vol. 4, No. 2, s. 180-187, } \\
\text { DOI: http://dx.doi.org/10.1177/1523422302004002007. }\end{array}$ & 45 & 4,50 \\
\hline 72 & $\begin{array}{l}\text { Hyland T., Behaviourism and the meaning of competence, } \\
\text { w: Hodkinson P., Isett M. (eds.), The challenge of } \\
\text { competence, Cassell, London } 1995 .\end{array}$ & 75 & 4,41 \\
\hline 73 & $\begin{array}{l}\text { Wolf A., Competence-based assessment: does it shift the } \\
\text { demarcation line?, w: Nijhof W. J., Streumer J. N. (eds.), } \\
\text { Key qualifications in work and education, Kluwer Academic } \\
\text { Press, Dordrecht 1998, s. 207-220, } \\
\text { DOI: http://dx.doi.org/10.1007/978-94-011-5204-4_13. }\end{array}$ & 60 & 4,29 \\
\hline 74 & $\begin{array}{l}\text { Kolb D. A., Experiential Learning. Englewood Cliffs, Prentice } \\
\text { Hall, New York } 1984 .\end{array}$ & 112 & 4,00 \\
\hline
\end{tabular}


Załącznik nr 1 - cd.

\begin{tabular}{|c|c|c|c|}
\hline Lp. & Nazwa badania/Autor i tytuł publikacji & $\begin{array}{l}\text { Liczba } \\
\text { cytowań } \\
\text { w Google } \\
\text { Scholar }\end{array}$ & $\begin{array}{c}\text { Współczynnik } \\
\text { ważności }\end{array}$ \\
\hline 75 & $\begin{array}{l}\text { Heidemann W. et al., Validation and recognition of } \\
\text { competences and qualifications: European discussion paper } \\
\text { for the social partners: final report of Leonardo da Vinci } \\
\text { project VALID, Hans Böckler Stiftung, Düsseldorf } 1998 .\end{array}$ & 49 & 3,50 \\
\hline 76 & $\begin{array}{l}\text { Hunter G., Abelmann N. et. al., Interrogating the University, } \\
\text { One (Archival) Entry at a Time, "Change: The Magazine } \\
\text { of Higher Learning" 2008, Vol. 40, No 5, s. 40-45, } \\
\text { DOI: http://dx.doi.org/10.3200/CHNG.40.5.40-45. }\end{array}$ & 12 & 3,00 \\
\hline 77 & $\begin{array}{l}\text { Zenke S., Zenke R., Putting competencies to work, } \\
\text { "Training" 1999, Vol. 36, No. 1, s. 70-76. }\end{array}$ & 38 & 2,92 \\
\hline 78 & $\begin{array}{l}\text { Spencer L. M., McClelland D. C., Kelner S., Competency } \\
\text { assessment methods: history and state of the art, Hay/ } \\
\text { /McBer, Boston } 1997 .\end{array}$ & 43 & 2,87 \\
\hline 79 & $\begin{array}{l}\text { Chisholm L., Spannring R., Mitterhofer H., Competence } \\
\text { development as workplace learning in German-speaking } \\
\text { Europe, Insbruck University Press, Insbruck } 2007 .\end{array}$ & 14 & 2,80 \\
\hline 80 & $\begin{array}{l}\text { Athey T. R., Orth M. S., Emerging competency methods for } \\
\text { the future, "Human Resource Management" 1999, Vol. 38, } \\
\text { No. 3, s. 215-226, } \\
\text { DOI: http://dx.doi.org/10.1002/(SICI)1099- } \\
\text { 050X(199923)38:3<215::AID-HRM4>3.0.CO;2-W. }\end{array}$ & 36 & 2,77 \\
\hline 81 & $\begin{array}{l}\text { Stewart J., Hamlin B., Competency-based qualifications: } \\
\text { the case for established methodologies, "Journal of } \\
\text { European Industrial Training" 1992, Vol. 16, } \\
\text { No. 10, s. 9-16, } \\
\text { DOI: http://dx.doi.org/10.1108/03090599210021702. }\end{array}$ & 53 & 2,65 \\
\hline 82 & $\begin{array}{l}\text { Mathewman J., Trends and developments in the use of } \\
\text { competency frameworks, "Competency" 1995, } \\
\text { Vol. 1, No. 4. }\end{array}$ & 45 & 2,65 \\
\hline 83 & $\begin{array}{l}\text { Wood R., Power C., Aspects of the competence- } \\
\text { performance distinction: educational, psychological } \\
\text { and measurement issues, "Journal of Curriculum Studies" } \\
\text { 1987, Vol. 19, No. 5, s. 409-424, } \\
\text { DOI:.http://dx.doi.org/10.1080/0022027870190503 }\end{array}$ & 329 & 2,63 \\
\hline 84 & $\begin{array}{l}\text { Bergenhenegouwen G. J., Ten Horn H. F. K., Mooijman } \\
\text { E. A. M., Competence development - a challenge for } \\
\text { HRM professionals: core competences of organisations } \\
\text { as guidelines for the development of employees, "Journal } \\
\text { of European Industrial Training" 1996, Vol. 20, No. 9, } \\
\text { s. 29-35, }\end{array}$ & 42 & 2,63 \\
\hline
\end{tabular}


Załącznik nr 1 - cd.

\begin{tabular}{|c|c|c|c|}
\hline Lp. & Nazwa badania/Autor i tytuł publikacji & $\begin{array}{l}\text { Liczba } \\
\text { cytowań } \\
\text { w Google } \\
\text { Scholar }\end{array}$ & $\begin{array}{c}\text { Współczynnik } \\
\text { ważności }\end{array}$ \\
\hline 85 & $\begin{array}{l}\text { Cseh M., Facilitating learning in multicultural teams, } \\
\text { "Advances in Developing Human Resources" 2003, } \\
\text { Vol. 5, No. 1, s. 26-40, } \\
\text { DOI: http://dx.doi.org/10.1177/1523422302239181. }\end{array}$ & 23 & 2,56 \\
\hline 86 & $\begin{array}{l}\text { Hirsh W., Strebler M., Defining managerial skills and } \\
\text { competences, w: Mumford A. (ed.), Gower Handbook } \\
\text { of Management Development, Gower, Aldershot 1994, } \\
\text { s. 79-96. }\end{array}$ & 46 & 2,56 \\
\hline 87 & $\begin{array}{l}\text { de Kraker J., Lansu A., van Dam-Mieras R. (eds.), } \\
\text { Crossing boundaries. Innovative learning for sustainable } \\
\text { development in higher education, VAS, Frankfurt on the } \\
\text { Main } 2007 .\end{array}$ & 10 & 2,50 \\
\hline 88 & $\begin{array}{l}\text { Hoskins B., Deakin Crick R., Competencies for learning } \\
\text { to learn and Active Citizenship, Joint Research Centre } \\
\text { European Commission, Ispra, Italy } 2008 .\end{array}$ & 10 & 2,50 \\
\hline 89 & $\begin{array}{l}\text { Field J., Reality testing in the workplace: are NVQs } \\
\text { "employment-led"?, w: Hodkinson P., Issitt M. (eds.), } \\
\text { The challenge of competence, Cassell Education, } \\
\text { London } 1995 .\end{array}$ & 42 & 2,47 \\
\hline 90 & $\begin{array}{l}\text { Barnett R., Limits of competence: knowledge, higher } \\
\text { education and society, Open University Press, London } \\
1994 .\end{array}$ & 41 & 2,28 \\
\hline 91 & $\begin{array}{l}\text { Robotham D., Jubb R., Competences: measuring the } \\
\text { unmeasurable, "Management Development Review" 1996, } \\
\text { Vol. 9, No. 5, s. 25-29, } \\
\text { DOI: http://dx.doi.org/10.1108/09622519610131545. }\end{array}$ & 35 & 2,19 \\
\hline
\end{tabular}


Załącznik 2: Polskojęzyczne publikacje w Google Scholar

\begin{tabular}{|c|c|}
\hline Hasła & Wyniki \\
\hline $\begin{array}{l}\text { kompetencje/kwalifikacje } \\
\text { społeczne; } \\
\text { kompetencje/kwalifikacje } \\
\text { kluczowe; } \\
\text { kompetencje/kwalifikacje } \\
\text { miękkie; kompetencje } \\
\text { adaptacyjne, } \\
\text { kompetencje emancypacyjne, } \\
\text { kompetencje krytyczne, } \\
\text { zdolności społeczne } \\
\text { umiejętności społeczne }\end{array}$ & $\begin{array}{l}\text { 1. Aleksander T., Skrzypczak J. (red.), Edukacja ustawiczna } \\
\text { w zmieniającej się sytuacji edukacyjnej (wybrane } \\
\text { problemy), Poznań } 1998 . \\
\text { 2. Argyle M., Zdolności społeczne, w: Moscovici S. (red.), } \\
\text { Psychologia społeczna relacji ja-inni, WSiP, Warszawa } \\
\text { 1998. } \\
\text { 3. Bąk E., Bobrowska-Jabłońska K., Iwanow A., Kompetencje } \\
\text { społeczne studentów Szkoły Głównej Handlowej a wybór } \\
\text { specjalizacji i preferowany charakter pracy, Centrum } \\
\text { Pedagogiczne SGH, Warszawa 1998. } \\
\text { 4. Czejkowska I., Pasieka D., Program „Kreator". Kompetencje } \\
\text { kluczowe w szkole, Kraków 1998. } \\
\text { 5. Dziedzic B., Technologia informacyjna w kształceniu } \\
\text { praktycznych umiejętności społecznych, w: Migdałek J. } \\
\text { (red.), Techniki komputerowe w przekazie edukacyjnymi, } \\
\text { Warszawa 2002. } \\
\text { 6. Filipowicz G., Zarządzanie kompetencjami zawodowymi, } \\
\text { Warszawa 2004. } \\
\text { 7. Hamer H., Rozwój umiejętności społecznych - jak } \\
\text { skutecznie dyskutować i współpracować, Warszawa 1999. } \\
\text { 8. Okońska-Walkowicz A., Plebańska M., Szaleniec H., } \\
\text { O kompetencjach kluczowych, e-learningu i metodzie } \\
\text { projektów, Warszawa 2009. } \\
\text { 9. Pietruszka-Ortyl A., Kluczowe kompetencje aliantów } \\
\text { potencjałem strategicznym kooperacji, w: Ciska M. (red.), } \\
\text { Kapitał relacyjny w nowoczesnej gospodarce, Warszawa } \\
\text { 2009. } \\
\text { 10. Smółka P., Kompetencje społeczne: metody pomiaru } \\
\text { i doskonalenia umiejętności interpersonalnych, Warszawa } \\
\text { 2008. }\end{array}$ \\
\hline
\end{tabular}


Załącznik 3: Kwerenda biblioteczna w Uniwersytecie Mikołaja Kopernika

\begin{tabular}{|c|c|}
\hline Hasła & Literatura \\
\hline $\begin{array}{l}\text { kompetencje/ kwalifikacje } \\
\text { społeczne, } \\
\text { kwalifikacje zawodowe } \\
\text { kompetencje/kwalifikacje } \\
\text { kluczowe } \\
\text { kompetencje/kwalifikacje } \\
\text { miękkie, kompetencje } \\
\text { adaptacyjne/krytyczne/ } \\
\text { /emancypacyjne, } \\
\text { zdolności społeczne, } \\
\text { umiejętności społeczne }\end{array}$ & $\begin{array}{l}\text { 1. Ditta Baczała, Niepełnosprawność intelektualna } \\
\text { a kompetencje spoteczne, Toruń: Wydawnictwo UMK } 2012 . \\
\text { 2. Tomasz P. Czapla, Modelowanie kompetencji pracowniczych } \\
\text { w organizacji, Łódź: Wydawnictwo Uniwersytetu Łódzkiego, } \\
\text { 2012. } \\
\text { 3. Marta Czechowska-Bieluga, Anna Kanios, Ewa Sarzyńska, } \\
\text { Profile kompetencji społecznych osób pracujących } \\
\text { i bezrobotnych, Lublin: Wydawnictwo Uniwersytetu Marii } \\
\text { Curie-Skłodowskiej, 2009. } \\
\text { 4. Waldemar Furmanek, Umiejętności technologiczne uczniów } \\
\text { szkół ogólnokształcących, Rzeszów: Wydaw. Wyższej Szkoły } \\
\text { Pedagogicznej, 1986. } \\
\text { 5. Waldemar Furmanek, Milan Ďuriš (red.), Kompetencje } \\
\text { kluczowe kategorią pedagogiki: studia porównawcze } \\
\text { polsko-słowackie, Rzeszów: Wydawnictwo Uniwersytetu } \\
\text { Rzeszowskiego, 2007. } \\
\text { 6. Beata Gumienny, Kompetencje społeczne niepełnosprawnych } \\
\text { intelektualnie wychowanków domów dziecka, Rzeszów: } \\
\text { Wydawnictwo Uniwersytetu Rzeszowskiego, 2010. } \\
\text { 7. Anna Kanios, Społeczne kompetencje studentów do pracy } \\
\text { w wolontariacie, Lublin: Wydawnictwo Uniwersytetu Marii } \\
\text { Curie-Skłodowskiej, 2010. } \\
\text { 8. Marcin Kęsy, Kompetencje zawodowe młodych: możliwości } \\
\text { szkolnictwa zawodowego a potrzeby pracodawców, Kraków: } \\
\text { Wydawnictwo Uniwersytetu Jagiellońskiego, cop. 2008. } \\
\text { 9. Gail King, Umiejętności terapeutyczne nauczyciela, (przekł. } \\
\text { Jolanta Bartosik), Gdańsk: Gdańskie Wydaw. Psychologiczne, } \\
\text { 2003. } \\
\text { 10. Stanisław Konarski (red.), Kompetencje społeczno- } \\
\text {-psychologiczne ekonomistów i menedżerów: teoria, } \\
\text { badania, edukacja, Warszawa: Szkoła Główna Handlowa, } \\
\text { 2006. } \\
\text { 11. Stanisław Konarski, Dariusz Turek (red.), Kompetencje } \\
\text { transferowalne: diagnoza, kształtowanie, zarządzanie, } \\
\text { Warszawa: Szkoła Główna Handlowa. Oficyna Wydawnicza, } \\
\text { 2010. } \\
\text { 12. Wojciech Knieć (red.), Umiejętność konsultacji społecznych } \\
\text { na styku inwestycje - środowisko drogą } \\
\text { do zrównoważonego rozwoju, Kraków: [PROxIMA coRP, } \\
\text { Dariusz Musiał], 2010. } \\
\text { 13. Wiesława Limont, Joanna Cieślikowska i Joanna Dreszer } \\
\text { (red.), Zdolności, talent, twórczość, t. } 1 \text { i t. 2, Toruń: } \\
\text { Wydawnictwo Naukowe Uniwersytetu Mikołaja Kopernika, } \\
\text { 2008. }\end{array}$ \\
\hline
\end{tabular}


Załącznik nr 3 - cd.

\begin{tabular}{|c|c|}
\hline Hasła & Literatura \\
\hline & 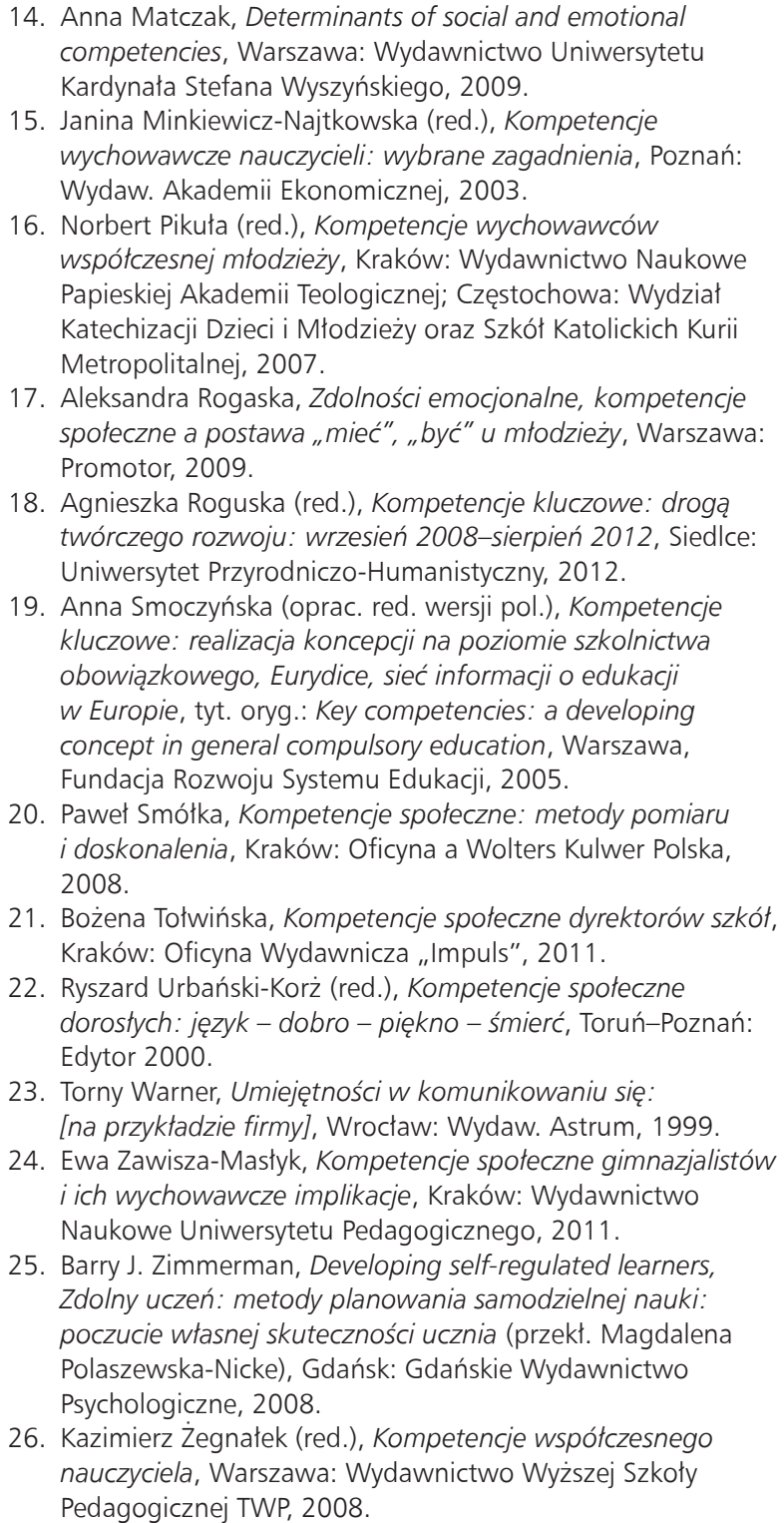 \\
\hline
\end{tabular}




\section{Literature review of key research on social competency in Polish and worldwide higher education}

\section{Summary}

The aim of the study is to review literature which according to the chosen criteria has had impact on understanding, practice of teaching and validating or neglecting social competency of higher education students. The method was based on using quotation indicators from Google Scholar search engine by entering key words or authors and dividing the number by years passed from publication. Competency is understood as synergy of knowledge, skills and attitudes successfully applied to complex tasks appreciated by specific environments. In relation to educational goals social competencies are categorized into adaptive, emancipatory and critical and so are the publications analyzed. The quantative results by quotation status indicate the dominance of literature on adaptive and instrumental functions of social competency which serves neoliberal ideology and represent the interests of employers and corporations. They are useful, however, for stakeholders of higher education as they point to specific methods of learning, teaching and validating social competency. The qualitative results focus on emancipatory and critical thinking competencies confirming that social ties, trust and collaboration are crucial both for new knowledge creation and innovation. Intercultural aspects and implications for educational change in academia as well as methodological limitations are included in the study.

Keywords: social competency, teaching, validating social competency. 